\title{
Study on the impact of Internet Finance on Commercial Banks in China
}

\author{
SU Yi Li ${ }^{1, a}$, LIU Fang ${ }^{2, b^{*}}$ \\ 1 J.X Street 768\# of Cheng Gong New Area, Kunming Yunnan, P.R. China \\ 2 J.X Street 768\# of Cheng Gong New Area, Kunming Yunnan, P.R. China \\ asuyili0814@163.com, b liufang198@163.com \\ * Corresponding author
}

Keywords: Internet Finance; Commercial Banks; Fintech.

\begin{abstract}
The development of Internet Finance is not only a challenge, but also an opportunity for traditional commercial banks, especially for the joint-stock commercial banks that owns a large share in China. Under the situation of Internet Finance development in China, this paper analyzed detailed the influence of internet finance on the tradition commercial banks by normal and empirical methods. The results show that impact of internet finance on the banks via its asset business, liability business and intermediary business, which will lead to the trend of financial disintermediation and finally threaten the operating performance, business model of commercial bank. We suggest that the commercial banks should change the mode of traditional operation and put forward more financial products using Fintech in the "Internet + Finance" era.
\end{abstract}

\section{Introduction}

As a new form in China, "Internet + finance", which is integrated by Internet Company and the financial industry, has little influence on the commercial banks because of that short duration and small scale. Retail industry[1], however, is the first to subject to the impact of "Internet + finance" with the commodity economic development and internet technology nowadays.

What and how the internet finance to impact on the banks? Taking the retail industry as an example, many scholars has been conducted deepen analysis it, which based on the upstream and downstream value chain throughout the retail industry[2]. As it likes the banks, this article also concentrates on three plates of joint-stock commercial banks to study the influences of Internet finance on the joint-stock commercial banks in order to change the situation of challenge that banks confront into the advantages of opportunity in the Fintech era.

\section{The Impact of Internet Finance on Debt Business}

Internet finance can shunt the liabilities of commercial banks. As we known, Debt business is the foundation of the commercial bank's asset business and intermediary business, which is the basic business in its operations and developments. Accordingly, for the development mode of Internet Finance, the third party payments and Internet funds have a convenient function for saving money. There is no doubt that this will inevitably diffuse social savings in banks to a certain extent [3].

Firstly, we analyze the overall situation of RMB deposit, and found that the Whole debt business of traditional commercial bank has been maintained at a high level of growth, no less than two digit growth, but the RMB deposit balance growth rate fell significantly from 2010 to 2014, the average deposit balance growth remained at $12.36 \%$, but the growth rate is below average growth rate in 2015.

Secondly, we focus on the loan over deposit ratio of the 12 joint-stock commercial banks in China. As the figure 1 shows that 12 joint-stock bank loan over deposit ratio is continued to rise and reached the highest level in 2014, even gradually approaching the upper limit $75 \%$ regulated by the central bank. Alibaba's Yue bao, a third party payment of Internet Finance, is amount to 578.9 billion Yuan in 2014 from 185.3 billion Yuan in 2013, which has been increased 3.12 times. The amount of China's 
Internet funds, however, can be as high as 2249.3 billion Yuan in 2013, which is driven sharply by Yuebao over the past years. In recent years, internet funds have been in an upward trend, and reached 7767.3 billion Yuan in 2015.

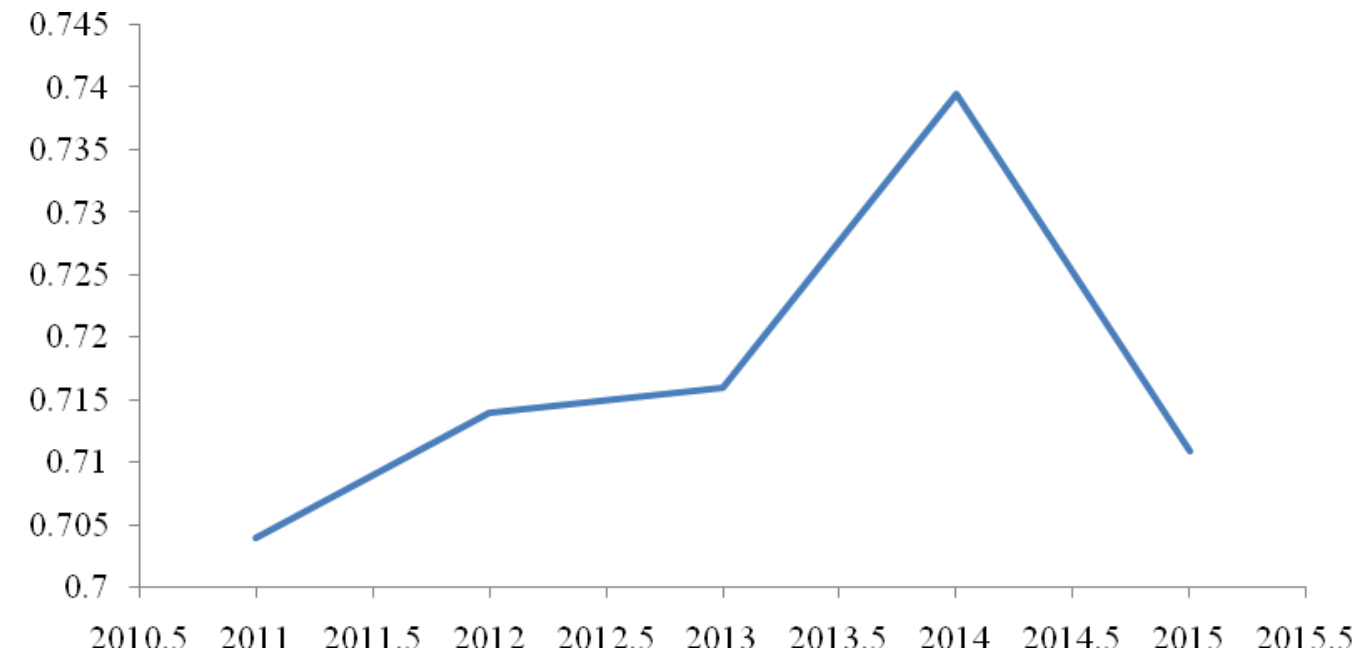

Fig.1. 12 joint-stock commercial banks loan over deposit ratio

From the analysis above, we know that the size of Internet fund and Yuebao is on the increase, while the joint-stock commercial bank loan over deposit ratio is declining in deposits. The results illustrate that Internet financial products have begun to shunt the commercial bank debt business and the impact on the joint-stock business actually through the capital value chain upstream suppliers to affect its debt business.

\section{The impact of Internet finance on asset business}

Internet finance can squeeze the asset business of commercial bank. The asset business of commercial banks refers to usage of funds for commercial bank, an activity of commercial banks to absorb the funds to lend or invest in order to earn money.

Commercial bank' profitability and business success largely depends on the results of the use of funds. The flow of assets and loans is primarily directed towards the downstream customers of the capital value chain. At present, the loan business of commercial banks is less than the financial needs of customers. From the macro level, the loan business also depends on the macroeconomic environment, the money supply and so on. The loan business of commercial banks will be proportional to the macroeconomic environment, and gradually change from the seller's market to the buyer's market with the improvement of economic situation [4].

According to "2015 financial institutions loan investment report", the loan balance of financial institutions reached 93950 billion Yuan, while small and micro enterprises is 17390 billion Yuan, which was increased $13.9 \%$ at the end of 2015. In addition, the balance of small and micro enterprise loans accounted for $31.2 \%$ of the balance of corporate loans.

But, in the first 9 months of 2015, the country's newly registered enterprises run up to 11.6 thousand households in the average daily with high growth, small and micro enterprises accounted for about $96.62 \%$ of the total number of newly registered enterprises as shown in the development of the national market players in the third quarter of 2015. Small and micro enterprises' overwhelming pattern gradually revealed and confront with much money for operation. Hence, the internet finance, especially $\mathrm{P} 2 \mathrm{P}$ and fund can be alternative for commercial banks in small and micro enterprise's loans, which will definitely squeeze and occupy commercial banks' loan business for small and micro enterprise. 


\section{The impact of Internet Finance on intermediary business}

Internet Finance can compress the commercial banks intermediary business. The intermediary business of commercial banks refers to business of collecting fees as a commercial agent, which makes collection, pay a sum of money and deal with other matters entrusted for customers. Their service object involves the upstream and downstream customers of the capital value chain.

According to "A study on intermediary business of commercial banks" in 2015, clearing and settlement, agency business, bank cards etc, this has become the main source of income for the intermediary business of commercial banks [5]. The rise of the third party payment, however, under Internet Finance by virtue of its size and the advantage squeezed again intermediate business.

The scale of China's third party payment transactions is increasing year-on-year as shown in table 1. The amount of the third party payment was more than 20 trillion in 2014 and 2015, and the average transaction amount of third party Internet payment exceeded $\$ 10$ trillion, its average is already 2 times than that in 2013. Third party mobile payment transaction size in 2015 has exceeded $\$ 10$ trillion, which has increased by 2 times compared with the previous year.

Table1 the size of third party payment transaction in 2011-2015 (Unit: Trillion Yuan)

\begin{tabular}{|c|c|c|c|c|c|}
\hline year & 2011 & 2012 & 2013 & 2014 & 2015 \\
\hline Third party payment transaction scale & 8.4 & 12.4 & 17.2 & 23.3 & 21.1 \\
\hline Third party Internet payment transaction scale & 2.2 & 3.66 & 5.37 & 8.08 & 11.9 \\
\hline Third party mobile payment transaction size & 0.0799 & 0.1511 & 1.2197 & 5.9924 & 10.1713 \\
\hline
\end{tabular}

while as the "China online banking market quarterly monitoring report for the fourth quarter in 2015 "shows that China's online banking customer transactions have been reached $\$ 510$ trillion, the proportion of its online banking payment is only $17.6 \%$. But take the cost as an example, In terms of bank card fees, the cost of the third party payment is lower, both the transfer cost of Artificial counter and online banking of joint stock commercial bank is $0.1 \%-1 \%$, no more than 50 Yuan; CITIC Bank transfer cost reach up to $1 \%$, but as a joint-stock commercial bank, Min sheng Bank, it's transfer cost is only $0.1 \%$, the cost is different, but it indeed exists.

However, Ali pay, as a representative of the third party payment, the transfer is free of charge. What's more, there are a series of advantages, such as timely arrival of cash, Quick, Support balance, bank card, credit card consumption and no limit. In addition, the same platform interface of Third party payment administrated multiple bank accounts. It is not difficult to see the continual innovation in business mode of the third party payment of Internet Finance and they can deeply influence on commercial banks in the future.

\section{Conclusion}

Our analysis indicates that internet finance has a significant effect on commercial banks. From the perspective of debt business, asset business and intermediary business for 12 commercial banks in China, we find that internet finance can shunt the liabilities, squeeze the asset business and compress intermediary business of commercial banks with the development of diversity of internet finance in China.

One should be careful in attaching normative implication to these findings. Yet, the results reported in this paper may provide some guidelines to bankers. For example, in an era of Fintech, manager should change the tradition mode of banks and make more financial products to satisfy difference customer needs for more finance services in the new economic era.

\section{Acknowledgements}

This paper was financial supported by the young project of Yunnan Provincial Department of Science and Technology "The Effects of RMB Cross-Border Direct Investment and Financing in Yunnan: Based on the Opening DSGE Model" (2015FD017) and also is financial supported by the PhD fund of Yunnan Normal University that is "Research on the Interest Groups and Finance Development in Theoretic and Empirical” (140082). 


\section{References}

[1] Syed,A.R., Nida,H.,. Journal of Electronic Finance,Vol.7,No.1(2013),p.88-96

[2] Z.L,Zheng.Finance \& Economics,No.5(2015),p.34-43

[3] J.H,Wang. The Theory and Practice of Finance and Economics, Vol.36,No.193(2015),p.8-11

[4] Caffard, Christophe..International Financial Law Review No.10(2014),p.20-24

[5] Ramsey. The Journal of International Finance No.2(2014),p.31-49 